ŠTĚPÁN BALÍK

(1) HTTP://ORCID.ORG/ 0000-0002-6463-1253

Jihočeská Univerzita v Českých Budějovicích

e-mail: balik@ff.jcu.cz

AGATA FIRLEJ

(1) HTTP://ORCID.ORG/ 0000-0002-3928-1079

Uniwersytet im. Adama Mickiewicza w Poznaniu

e-mail: afirlej@amu.edu.pl

ELISA-MARIA HIEMER

(i) HTTP://ORCID.ORG/ 0000-0003-2223-6172

Herder-Institut für historische Ostmitteleuropaforschung, Marburg

e-mail: elisa-maria.hiemer@herder-institut.de

JIŘí HOLÝ

(1) HTTP://ORCID.ORG/ 0000-0002-6867-6109

Univerzita Karlova, Praha

e-mail: jiri.holy@ff.cuni.cz

D. HTTP://ORCID.ORG/ 0000-0002-2400-4036

HANA NICHTBURGEROVÁ

Univerzita Karlova, Praha

e-mail: hnichtburgerova@gmail.com

\title{
Handbook of Polish, Czech and Slovak Holocaust Fiction. Works and Contexts. A Short Introduction to the Project with Two Entries
}

\begin{abstract}
Handbook of Polish, Czech and Slovak Holocaust Fiction is a work in progress aiming at becoming a standard reference work addressed to universities and public libraries and the broader public. It includes novels, short stories, poems and plays written in Polish, Czech and Slovak within the scope of 650 standard pages. The table of contents consists of 53 articles focused on Polish, 45 articles on Czech, and 23 articles on Slovak literature. The editors provide an introduction about the main developments of Holocaust literature in the broader context of three lands: crucial topics, situations, characters, motifs and places, periodization due to political changes, reception processes in the national and transnational context. The Handbook aims primarily at the researchers and readers in Western Europe and the U.S. where the Polish, Czech and Slovak Holocaust fiction remains largely unknown. The project results from the cooperation among researchers from Polish, Czech, German and Slovak universities. This article presents two entries from Polish and Czech literature.
\end{abstract}


Keywords: Holocaust literature, Polish, Czech, Slovak, Handbook, Piotr Paziński, third generation prose, periphery, retirement home, Radek Malý, taboo-breaking rhymes, grotesque, public debate

The project handbook results from a long-term cooperation of the Polish-Czech-German team consisting of researchers in the subject of Slavonic and Comparative Studies. During the last 10 years, this team has published about a dozen books in various languages and organized eight international workshops concerning the Holocaust in Central European literatures and cultures. ${ }^{1}$ Throughout these years, our team noticed a gap between the literary production in the countries where the Holocaust mainly took place and their response in the non-Slavonic world. For this reason, we are going to edit a handbook with works, originally published in Polish, Czech or Slovak that are of importance not only for these literatures but also for the worldwide research on Holocaust literature. Additionally, this project has been joined by Slovak researchers.

We aim at making these literatures visible for non-Slavonic recipients to overcome the lack of their presence in Holocaust Studies. By improving the visibility of "small" literatures, we hope to encourage publishing houses to commission translations. From the quantitative point of view the underrepresentation looks as follows: The Reference Guide to Holocaust Literature ${ }^{2}$ presents 225 authors but only 2 of them were of Czech origin, 3 of Slovak. A slightly better situation is noticeable for Polish authors: 23 positions. In Holocaust Literature.

${ }^{1}$ Holokaust v české, slovenské a polské literatuře, ed. J. Praha 2007; J. Holý, P. Málek, M. Špirit, F. Tomáš, Šoa v české literatuře a v kulturni paméti, Praha 2011; The Representation of the Shoah in Literature, Theatre and Film in Central Europe: 1950s and 1960s, ed. J. Holý, Praha 2012; The Representation of the Shoah in Literature and Film in Central Europe: 1970s and 1980s, ed. J. Holý, Praha 2012, E.-M. Hiemer, Generationenkonflikt und Gedächtnistradierung. Die Aufarbeitung des Holocaust in der polnischen Erzählprosa des 21. Jahrhunderts, Stuttgart 2012; B. Krupa, Opowiedzieć Zagładę: polska proza i historiografia wobec Holocaustu (1987-2003), Kraków 2013; Der Holocaust in den mitteleuropäischen Literaturen und Kulturen nach 1989. The Holocaust in the Central European Literatures and Cultures since 1989, ed. R. Ibler, Stuttgart 2014; Reprezentacje Shoah w literaturze i filmie w Europie Środkowej: lata powojenne, "Acta Universitatis Lodziensis. Folia Scientiae Artium et Litterarum", eds. G. Gazda, M. Leyko, P. Rutkiewicz, Łódź 2014; The Aspects of Genres in the Holocaust Literatures in Central Europe. Die Gattungsaspekte der Holocaustliteratur in Mitteleuropa, ed. J. Holý, Praha 2015; Š. Balík, Jidiš v židovském etnolektu a moderní židovská literární identita $v$ Čechách, Praha 2015; Der Holocaust in den mitteleuropäischen Literaturen und Kulturen: Probleme der Poetisierung und Ästhetisierung. The Holocaust in the Central European Literatures and Cultures: Problems of Poetization and Aestheticization, ed. R. Ibler, Stuttgart 2016; Cizí i blizcí. Židé, literatura, kultura v českých zemích ve 20. století, ed. J. Holý, Praha 2016; A. Firlej, Nieobecność. Ujęcia Szoa w czeskiej dramaturgii, Poznań 2016; Recepcja literackich i artystycznych dzieł o Szoa, ed. A. Firlej, [particular issue in:] „Poznańskie Studia Slawistyczne” 2017, nr 12; Š. Sladovníková, The Holocaust in Czechoslovak and Czech Feature Films, Stuttgart 2018; E.-M. Hiemer, Autobiographisches Schreiben als ästhetisches Problem. Jüdische Vielfalt in der polnischen und deutschen Gegenwartsliteratur, Wiesbaden 2019.

2 Reference Guide to Holocaust Literature, Ed. T. Detroit etc. 2002. 
An Encyclopedia of Writers and Their Work ${ }^{3}$, out of 312 entries, we count 31 Polish, 3 Czech and not a single Slovak entry. In Holocaust Novelists ${ }^{4}$ it is 3 Polish and 4 Czech authors out of 43 articles. The entry about Holocaust literature in the Oxford Handbook of Holocaust Studies ${ }^{5}$ mentions 3 Polish authors but no one from Czech or Slovak origin.

All entries will be edited in accordance with scientific standards, but also written in a way that encourages the broader public to learn more about this topic. Each entry contains practical information (about translations, film adaptions, the author) but mainly focuses on a short summary of the plot and a review of the main issues and problems. We pay attention to the comparative aspect which means that the articles contain cross-references to other entries in the book (marked by an arrow $\rightarrow$ ) but also to motifs, topics, characters, situations and literary devices mentioned in others books (Aryan Papers, beautiful Jewess, child's narration, postmemory, Terezín Ghetto, etc.). The articles give not only an overview of the main topics but also help to understand the specific national, historical context and discussion in the countries of origin. The works are contextualized which is indispensable for researchers from other philologies who aren't familiar with the historical and sociocultural context. Every entry ends with a short, selected biography that also considers English references to encourage the readers to further studies.

Although we consider all of the three mentioned literatures ${ }^{6}$ to be underrepresented in the current Holocaust Research, the hugest desideratum is clearly the Slovak literature. The handbook wants to increase the visibility and the versatileness all of these literatures in the academia dealing with the representation of the Holocaust in arts. Furthermore, we provide not only encyclopaedic knowledge about the literary output of this region but also an overview of the debates that accompanied the works and show similarities in narration and motif choice.

Publication of the Handbook is expected in 2021 in the publishing house DeGruyter, which is known for its Jewish Studies Series. We intend to increase the visibility of the project's outcome by realizing an Open Access Handbook and covering the printing costs of this hybrid publication type. To get a first impression, we present two entries below which represent Polish and Czech contemporary literature. In contrast to the customs of this journal, the articles itself are published in its assumed standard quotation of the Handbook (Harvard Style of Referencing).

3 Holocaust Literature: An Encyclopedia of Writers and Their Work, ed. S.L. Kremer, vol. 1. and 2, London-New York 2003.

4 Holocaust Novelists. Dictionary of Literary Biography 299, ed. Sicher, Detroit etc. 2004.

5 The Oxford Handbook of Holocaust Studies, eds. P. Hayes, J.K. Roth, Oxford etc. 2010.

6 The Handbook presents literature in Poland, Czechia and Slovakia in their three main languages: Polish, Czech and Slovak. If we had accepted the Yiddish literature it would have been necessary to accept also German speaking literature in Theresienstadt or Kosiński's The Painted Bird written in English and other works. 


\section{Bibliography}

Balík Š., Jidiš v židovském etnolektu a moderní židovská literární identita v Čechách, Praha 2015.

Cizi i blizcí. Židé, literatura, kultura včeských zemích ve 20. století, ed. J. Holý, Praha 2016.

Der Holocaust in den mitteleuropäischen Literaturen und Kulturen nach 1989. The Holocaust in the Central European Literatures and Cultures since 1989, ed. R. Ibler, Stuttgart 2014.

Der Holocaust in den mitteleuropäischen Literaturen und Kulturen: Probleme der Poetisierung und Ästhetisierung. The Holocaust in the Central European Literatures and Cultures: Problems of Poetization and Aestheticization, ed. R. Ibler, Stuttgart 2016.

Firlej A., Nieobecność. Ujęcia Szoa w czeskiej dramaturgii, Poznań 2016.

Hiemer E.-M., Autobiographisches Schreiben als ästhetisches Problem. Jüdische Vielfalt in der polnischen und deutschen Gegenwartsliteratur, Wiesbaden 2019.

Hiemer E.-M, Generationenkonflikt und Gedächtnistradierung. Die Aufarbeitung des Holocaust in der polnischen Erzählprosa des 21. Jahrhunderts, Stuttgart 2012.

Holocaust Literature: An Encyclopedia of Writers and Their Work, vol. 1, and 2, London-New York 2003.

Holocaust Novelists. Dictionary of Literary Biography 299, ed. E. Sicher, Detroit etc. 2004.

Holokaust v české, slovenské a polské literatuře, ed. J. Holý, Praha 2007.

Holý J., Málek P., Špirit M., Tomáš F., Šoa v české literatuře a v kulturní paměti, Praha 2011.

Krupa B., Opowiedzieć Zagładę: polska proza i historiografia wobec Holocaustu (1987-2003), Kraków 2013.

Recepcja literackich $i$ artystycznych dzieł o Szoa, ed. A. Firlej [particular issue in:] „Poznańskie Studia Slawistyczne” 2017, no 12.

Reference Guide to Holocaust Literature, ed. T. Riggs, Detroit etc. 2002.

Reprezentacje Shoah $w$ literaturze $i$ filmie $w$ Europie Środkowej: lata powojenne, eds. G. Gazda, M. Leyko, P. Rutkiewicz, "Acta Universitatis Lodziensis. Folia Scientiae Artium et Litterarum", Łódź 2014.

Sladovníková Š., The Holocaust in Czechoslovak and Czech Feature Films, Stuttgart 2018.

The Aspects of Genres in the Holocaust Literatures in Central Europe. Die Gattungsaspekte der Holocaustliteratur in Mitteleuropa, ed. J. Holý, Praha 2015.

The Oxford Handbook of Holocaust Studies, eds. Hayes, Roth, Oxford etc. 2010.

The Representation of the Shoah in Literature, Theatre and Film in Central Europe: 1950s and 1960s, ed. J. Holý, Praha 2012.

The Representation of the Shoah in Literature and Film in Central Europe: 1970s and 1980s, ed. J.Holý, Praha 2012. 


\title{
The Boarding House (Pensjonat)
}

\author{
Author: Piotr Paziński
}

First Published: 2009

Translations: Czech (Letni byt, 2012), German (Die Pension, 2013), Serbian (Pansion, 2013), Croatian (Pansion, 2014), French (Pension de famille, 2016), Slovenian (Penzion, 2016), Hungarian (Panzió, 2016), Italian (La pensione, 2016), Bulgarian (Pansionât, 2016), English (The Boarding House, 2018).

\begin{abstract}
About the Author: Piotr Paziński, born 1973 in Warsaw, holder of a PhD degree in Literature Studies, is one of the main contemporary representatives of the socalled third generation of Jews in Poland. Since 2000, he has held the role of editor-in-chief of the Jewish monthly Midrasz. Besides this, he also writes for Gazeta Wyborcza's culture and literature feature pages, appears as co-author of numerous publications of the Jewish Historical Institute in Warsaw and works as a translator from Hebrew. For his book Pensjonat, he received international attention after being awarded the European Union Prize for Literature in 2012.
\end{abstract}

Further Publications: Ptasie ulice (2013, The Birdy Streets; short stories); Rzeczywistość poprzecierana (2015, Frayed Reality; essays), Jerozolima: Książka do pisania (2018, Jerusalem: A book To Be Written; anthology)

\section{Content and Interpretation}

The idea of writing Boarding House was inspired by a longing for the author's childhood memories when he visited the guesthouse during the summer holidays. Paziński started making his first notes after a friend of his grandmother died. Inspired by the friend's destiny, he created the character of Ms. Tecia in the novella (Kęczkowska, 2009). The act of writing corresponds to the will to witness in order to rebuild places that were once centres of Jewish life and now seem to be offside in a geographical sense and offside in terms of commemoration. The story is about a short stay of an adult male with Jewish origins in the guesthouse Śródborowianka near Otwock, a city located in the southeast of Warsaw, where a few Jewish pensioners are spending not only their holidays, but their evening of life. The narrator's $\rightarrow$ flashbacks to his childhood show that the nowadays oldfashioned and unprofitable guesthouse used to be a vibrant and popular holiday destination for Jews from the whole country. The narrator's character is never described precisely and the pensioners are sceptical about his intentions at the beginning. Additionally, the young man puts himself into an observing and outstanding position by his extremely silent and reserved behaviour. On the one hand, his presence signifies for the elderly a new rise of interest in the Jewish history of Poland. The younger generation is looking for a kind of back-to-the-roots-experience. On the other hand, the pensioners have completely lost their belief in a Jewish future in their country and consider the narrator's growing interest to be pointless. 
The narrator faces an emotionally challenging stay. He is overwhelmed by the impressions of the pensioners' stories about the past, which he likes to enhance by his own imaginative power. At the same time, the trenchant discussions about Jewish religion lead by Mr. Abram and the complicated Polish-Jewish history after 1945, and more precisely the political crisis from 1968, show a gap of experiences the young man only knows from hearsay. At a certain point, the narrator's mood changes because he achieves an emotional and intellectual connection to these people who are living an isolated life, based on photographs and the power of narration.

My past is deep inside me, but when I try to get through to it, I encounter a hollow void, as if I was only born yesterday and all that happened before was just a tangle of blurred images (...) The amount of these images brings back the appearance of memories, just as the amount of photographs becomes a substitute for life. (...) And today I know that I have it from here, from this dining room comes my always accompanying feeling of living on an island, the feeling of inadequacy and inappropriateness (Paziński, 2009, p. 103).

After having silently observed the daily life in the guesthouse for two days, the narrator decides to leave. His way back to the train station turns into an oneiric situation: Summoned by Mr. Jakub, all the deceased and still alive Jews who the narrator has got to know through the pensioners' stories appear in a clearing in the nearby woods. At the very end, the narrator unexpectedly cries out his desire to stay and to be part of the eternal Jewish community.

\section{Main Topics and Problems}

Boarding House can be understood as a typical $\rightarrow$ postmemory narration that explores the syllable "post" not only in terms of time, but also in terms of distance from the generation of witnesses. The narrator takes delight in listening to the elderly. Their stories enable him to enter the unknown world of his ancestors, since the absence of the parents' generation signifies a break in the family's narration. The narrator tries to fill this gap by attending lessons in history and figuring out stories of the past motivated by objects such as photographs, postcards, newspapers, bills that the elderly, e.g. Ms. Tecia, have been collecting for almost a century. Similarly to other postmemory narrations such as those of Pawel Huelle Moving House and Other Stories (Opowiadania na czas przeprowadzki), the presence of objects means access to the past in a palpable way. The exclusive circle of the pensioners in this hardly accessible countryside guesthouse - which is a metaphor of not belonging to Poland - reminds the reader of a modern $\rightarrow$ Noah's Ark (Wróbel, 2013, p. 291, Kindermann, 2013, p. 267).

The book raises questions about how former Jewish places undergo a change of meaning, or how they can be reconstructed, or defended. Paziński's work can be examined in terms of spatial aspects and how space and narration correspond to each other. The location of Jews in the periphery makes the reader understand the loss of meaning and social status of Jewish citizens. The aspect of the city and countryside dyad is deepened in Paziński's second book The Birdy Streets (Ptasie ulice). The motif of the guesthouse or retirement home appears also in Zyta Rudzka's $\rightarrow$ Doctor Josef's Beauty and Stanisław Benski's $\rightarrow$ The Most 
Important Participle. Józef Wróbel explains this motif with the aura of wisdom and experience the elderly want to share. However, in Paziński's case, the stress is put on the generational gap and the problems connected with that: Storytelling helps connect the broken generational chain and give the individual an idea of their cultural origins. Nevertheless, they are not able to replace identity, since only a very abstract part of the narrator's personality becomes clearer. Additionally, the absence of the parents' generation makes it hard for the $\rightarrow$ third generation to get in contact with Jewish traditions and lifestyle. Boarding House serves as an example of the definition of Jewishness in 21st century Poland. (see also: Mikołaj Grynberg's $\rightarrow$ I Blame Auschwitz). The focus is not on the Holocaust itself, but on the Jewish-Polish relations before and after the Second World War. It is more about a feeling of being Jewish and the question of how Jewish origins influence someone's personality. This attitude demands not only a conscious remembrance of the genocide of the Jews in Europe but first of all the construction of positive references for Jewishness. In Boarding House, the narrator's childhood memories support the positive identity building processes. Therefore, more attention is paid to inventing and idealizing the past. At the same time, the focus on the past also denies options for the future. The omnipresence of Jewish traces and the high number of historical allusions going back to biblical parables only have an illustrative character and show a world that cannot be restored. Additionally, the narrator seems to be overextended by the denseness of historical references, which leads to an escape into fantasy and to a play between the ontological text levels (Hiemer, 2019, p. 111).

Cited Works: Paziński, P. (2009). Pensjonat. Warszawa: Nisza. Hiemer, E.-M. (2019). Autobiographisches Schreiben als ästhetisches Problem. Jüdische Vielfalt in der polnischen und deutschen Gegenwartsliteratur, Wiesbaden: Harassowitz. Kęczkowska, B. (2009). Pensjonat zapamiętany przez dziecko. Available at: http://warszawa.gazeta.pl/warszawa/1,34861,6810473,Pensjonat_zapamietany_przez_dziecko.html\#ixzz1Dx8qInsy [Accessed: 22.08.2018]. Kindermann, M. (2013): Zuhause im Text. Raumkonstitution und Erinnerungskonstruktion im zeitgenössischen anglo-jüdischen Roman, Berlin: Neofelis. Wróbel, J. (2013). Das jüdische Altersheim in der Literatur der Jahrhundertwende. In: K. Smola, ed., Osteuropäisch-jüdische Literaturen im 20. und 21. Jahrhundert. Identität und Poetik = Eastern European Jewish Literature of the 20th and 21st Centuries, München: Peter Lang, pp. 281-297.

Further References: Borowicz, J. (2015). Holocaust Zombies: Mourning and Memory in Polish Contemporary Culture. In: D. I. Popescu, T. Schulte, ed., Revisiting Holocaust Representation in the Post-Witness Era. The Holocaust and its Contexts. London: Palgrave Macmillan, pp. 132-148. Czemarmazowicz, M. (2011). Uporczywa ,pamięć” cudzej traumy. Reprezentacje Zagłady w nowszej literaturze polskiej. Przeglad Humanistyczny 2(425), pp. 123-134. Czyżak, A. (2013). Biografie polsko-żydowskie i żydowsko-polskie: rekonesans ponawiany. Poznańskie Studia Polonistyczne. Seria Literacka, 22(42), 
pp. 157-172. Hiemer, E.-M. (2019). Autobiographisches Schreiben als ästhetisches Problem. Jüdische Vielfalt in der polnischen und deutschen Gegenwartsliteratur, Wiesbaden: Harassowitz. Kaja, D. (2014). Kondycja człowieka/kondycja tekstu. O postpamięci w Pensjonacie Piotra Pazińskiego. In: D. Kaja, M. Wróblewski (ed.), O kondycji człowieka w polskiej literaturze najnowszej, Toruń: Wydawnictwo Naukowe Uniwersytetu Mikołaja Kopernika, pp. 117-132. Plaice, R. (2013). Holocaust memory in recent Polish literature: Andrzej Bart's Fabryka muchołapek and Piotr Paziński’s Pensjonat. Journal of European Studies, 1(41), pp. 34-49.

About the Contributor: Elisa-Maria Hiemer, Dr., postdoc researcher at Herder Institute for Historical Research on East Central Europe, Marburg

\section{Crow Songs (Vraní zpěvy)}

Author: Radek Malý

First Published: 2002

About the Author: Radek Malý (1977) studied Czech and German Studies at the Palacký University in Olomouc. Apart from teaching at the university and researching translatological tasks (e.g. two monographs reflecting Czech readings of Georg Trakl's and Paul Celan's work), he translates from German (especially expressionistic poetry) and is an editor of many anthologies of poems as well as the Czech anthology of German expressionistic poets. Although Radek Malý is also the author of plays and fairy tales, a representative part of his fictional production lies in poetry.

Further Important Publications: Lunovis (2001, Lunovis; poems); Vraní zpěvy (2002, Crow Songs; poems) Větrní: Zcestné verše (2005, Poems on the Road; poems); Spásná trhlina: Reflexe poezie Georga Trakla v české literatuře (2006; Redemptive Hole: Reflection of Georg Trakl's Poetry in Czech Literature; essays); Držíce v drzých držkách cigarety: Malá antologie poezie německého expresionismu (2007, Holding Cigarettes in their Traps: A Small Anthology of German Expressionistic Poetry); Malá tma (2008; Little Darkness; poems); Pocit nočního vlaku (2008, The Feeling of a Night Train; broadcasted also as a radio drama); Listonoš vítr (2011, Postman Wind; poems for children) Světloplaší (2012, The Light Shy; poems); Domovem v jazyce: České čtení Paula Celana. (2012, Resided in the Language: Reading Paul Celan in Czech); V̌sehomír (2015, Universe; poems); Franz Kafka - Člověk své a naši doby (2017; Franz Kafka - A Man of His Time and Our Own; essay, in Czech, German and English version). 


\title{
Content and Interpretation
}

The extraordinary position of Radek Malýs poetry in the context of fiction about the Shoah resides besides other things in the frequency of such motives. At least one Shoah motif is present in each collection of his poems. This theme also appears in his short play Pocit nočního vlaku (2008; The Feeling of a Night Train), naturally in his academic book about Celan, translations and in anthologies of Jewish authors (e.g. German Bohemian Hugo Sonnenschein, Vlastimil Artur Polák-Avalos) (cf. Holý, 2011, pp. 58-59; cf. Balík, 2015: pp. 232-234; cf. Balík, Holý, 2016, p. 503).

In his second collection of poems, Crow Songs, there are several motifs of the Shoah too. In the poem Buchenwald, 28. 11. 2000, he combined Czech high standard metric style dactyl (rhyme: ab-ab), colloquial language and fatal absurd grotesqu (cf. Kopáč, 2014).

\section{Prolapsed November \\ Drizzling gently down from grey clouds \\ A day perhaps only good enough \\ to visit a concentration camp}

You got up early after a binge

You see it in a non-conform way:

A hundred skeletons dressed in pyjamas

A few gods in uniforms

(Technical subject translation by Alexandra Šípová, also in other fragments of Malý's poems.)

\author{
Vyhřezlý listopad \\ Něžně mží z šedých mraků \\ Den vhodný leda snad \\ $\mathrm{K}$ návštěvě koncentráku \\ Přivstal sis po flámu \\ Vnímáš to nonkonformě: \\ Sto koster v pyžamu \\ Pár bohů v uniformě \\ (Malý, 2002, p. 34)
}

This poem is preceded by another two texts of this kind: iambic Jedem das Seine and trochaic Es ist mir trotzdem kalt. In the first one, Malý - fascinated by folk songs and nursery rhymes - elaborates two slogans, the first one from the gate in the Buchenwald camp, the other from Auschwitz. He creates an inappropriate absurd connection between the form with silly rhymes and the sense of Nazi propaganda hidden in defenceless words. Misusing the misused words 
Malý shifts the language back to its original basic meaning (Latin: suum cuique) (cf. Balík, 2015, p. 237).

\section{ARBEIT MACHT FREI.}

Ayay.

Ayayay.

\section{ARBEIT MACHT FREI.}

Ajaj.

Ajajaj.

(Malý, 2002, p. 32)

In the next poem Es ist mir trotzdem kalt, $\rightarrow$ Buchenwald and $\rightarrow$ Auschwitz appear explicitly. The fatal grotesque in form of a pun is elaborated by rhyming Osvétim (Auschwitz) with the verb posvétim (I will consecrate). The author also misuses the ambiguity of the phrase pridej plyn (step on the gas) (Malý, 2002, p. 33; cf. Balík, 2015, p. 238). "For Malý's poetry in general, it is significant that the Shoah is presented in the context of Germany, Sudetenland and CzechGerman relations. The $\rightarrow$ macaronic German-Czech verses, which appear in his texts very often, refer to this aspect as well as to the former partial bilinguality in the Czech Lands. All three poems dedicated to the Shoah here are included in the part with an odd title. It questions the German moral condition by putting together two contrasting texts: the well-known and very emotional inscription from Auschwitz and a traditional neutral name for a collection of poems: Arbeit macht frei. básně z Němec (Arbeit macht frei. poems from Germany)” (Balík, 2015, p. 238).

In general, there are two sources of Malý's inspiration. Firstly, his poetry is influenced by German (Georg Trakl, Georg Heym) and Czech expressionistic poetry (Bohuslav Reynek). One can find - aside from natural motifs - distinctive elements of eschatology and the grotesque.

Secondly, he is also inspired by the work of two poets from the former Jewish Austrian-Hungarian region Czernowitz (today in Ukraine) and thematising the Shoah in their poems, Rosa Ausländer and Paul Celan.

Consequently, Malý mentioned also Vlastimil Artur Polák-Avalos, who lived in Olomouc, the same Moravian town as Malý lives in, and especially his taciturn poem Ost-Transport (written 1944/1945, Transport to the East), of which he proposed the new translation (cf. Malý, 2014a, pp. 99-101). Whereas Celan and Polák wrote in German, their mother tongue, but also the language spoken by murderers of his relatives and friends (cf. Baer, 2002, p. 60), Malý, by writing in Czech (even though with macaronic elements) chooses a language of the by-standers, who were present in the time of destruction of their Jewish and then German neighbours' world, but who did nothing to save it.

In this context, it should be understood in the verses where the general "labels" of the Shoah (Auschwitz, well known Nazi slogans, gas, etc.) are mentioned. Malý uses these constant representations unusually to shock the reader and to force 
them to perceive these untouchable taboo symbols anew (Balík, 2015, p. 235). The rhyming words Faust - Holocaust or $\rightarrow$ Mengele - zbabělé (adjective "coward") (Malý, 2001, pp. 34-35; Malý, 2005, p. 17) are very striking especially in the context of his formally refined poetry. However, this kind of grotesque "misusing" of Holocaust cliché (also with the picture of Auschwitz doctor Mengele) is not unique in Czech literature. It can also be found in Arnošt Goldflam's play $\rightarrow$ At the Hitlers': The Hitler's Kitchen (cf. Schwarz, 2014, p. 163; cf. Balík, 2015, p. 235) or even in the 1960s in J. R. Pick's poems (Balík, 2017, p. 38). This shocking combination of simple childish form and the Shoah content was already deliberately used - as one of the first probably - by the Polish $\rightarrow$ Warsaw Ghetto poet Władysław Szlengel in the poem Mała stacja Treblinki (The Small Station Treblinka). However, in the poetry "hic et nunc", the motivation is rather different (cf. Balík, 2014, pp. 49-62). $\rightarrow$ Szlengel: Selected Poetry.

The question considering the appropriateness of Malýs treatment of the Shoah seems to be very important. However, the polemic that arose about this issue in Czech Jewish public forums revealed a possible misunderstanding of his specific poetic language. In 2013, a public debate about the meaning of one of his poems overlapped with literary discourse. CERMAT, the organisation in charge of preparing and assessing unified exams for students, chose Radek Malý's poem Buchenwald, 28.11.2000 as a part of the „Maturita“ Exam (the Czech equivalent of the British A-levels), without notifying the author (cf. Balík, 2015, p. 229).

Some authorities from the Czech Jewish community argued that such a choice in the context of the Maturita questions had relativised the suffering of the Shoah victims and offended the Czech Jews who lost their relatives during World War II, mainly in the last two verses: "You're half a Jew / and half an SS man" ("Je v tobě Žida půl / a půlka esesáka"). Radek Malý stated he had not relativised Jewish suffering during World War II and added that his proclamation was initiated by the ongoing reactions based on the confusion of the person of the author, his work and how his work was treated in public (Malý, 2014b).

Also according to Holý (2013) and Balík (2015, p. 231), these provocative poems were misinterpreted. Radek Malý's work provides clear evidence about his translatorial, scientific, artistic and also moral values.

Cited Works: Malý, R. (2001). Lunovis. Praha: BB art. Malý, R. (2002). Vraní zpěvy. Brno: Petrov. Malý, R. (2005). Větrní: Zcestné verše. Brno: Petrov. Malý, R. (2014a). Př́běhy básní a jejich překladi̊. Olomouc: Univerzita Palackého. Malý, R. (2014b). Available at: http://radekmaly.flexum.cz/?cs/ [Accessed 22.08. 2014].

Baer, U. (2002). Celan, Paul. In: T. Riggs, ed., Reference Guide to Holocaust Literature. Detroit: St. James Press, pp. 59-61. Balík, Š. (2014). Ewangelia o Treblince według Glazara, Rajchmana, Wiernika, Willenberga. In: G. Gazda et al., eds., Reprezentacje Shoah w literaturze i filme w Europie Środkowej: lata powojenne. Acta Universitatis Lodziensis. Folia Scientiae Artium et Litterarum, 11, pp. 49-62. Balík, Š. (2015). The Provocative Poetry of Radek Malý as a Tool for Dealing Appropriately with the Shoah. In: J. Holý, ed., Aspects of Genres in the 
Holocaust Literatures in Central Europe / Gattungsaspekte der Holocaustliteratur in Mitteleuropa. Praha: Akropolis, pp. 229-246. Balík, Š., Holý, J. (2016). Mezi tichem a křikem: Poezie o šoa. In: J. Holý, ed., Cizí i blizcí: Židé, literatura, kultura $v$ českých zemích ve 20. století. Praha: Akropolis, pp. 431-520. Balík, Š. (2017). Yelling into the Silence and its Echos: Czech Shoah Poetry Written till 1960s and its Reception. Poznańskie Studia Slawistyczne, (12), pp. 29-45. Holý, J. (2011). Židé a šoa $\mathrm{v}$ české a slovenské literatuře po druhé světové válce. In: J. Holý et al. Šoa v české literatuře a kulturní paměti. Praha: Akropolis, pp. 7-65. Holý, J. (2013). Pozoruhodná kniha Lukáše Přibyla a Michala Plzáka. Listy, 43 (6) [online]Availableat:at:http://www.listy.cz/archiv.php?cislo=136\&clanek $=061330$ [Accessed 26.04. 2019]. rk (=Kopáč, R.). (2014). Radek Malý (Archived profile). In: Czech Literature Portal [online] Available at: http://www.czechlit.cz/en/authors/maly-radek/author.profil/ [Accessed 14.09. 2014]. Schwarz, W. F. (2014). Holokaust und KZ im Fokus tschechischer Literatur nach 2000. Zu Arnošt Goldflams Doma u Hitlerů und Radka Denemarkovás Penize od Hitlera. In: R. Ibler, ed., Der Holocaust in den mitteleuropäischen Literaturen und Kulturen seit 1989. Stuttgart: ibidem-Verlag, pp. 157-171.

Further References: Munk, J., Papoušek, P. and Pavlát, L. (2013). Protest-CERMAT (17/05/2013). [online] Available at: http://www.fzo.cz/2058/protest-cermat/ [Accessed 26.04. 2019]. TJ (2013). Spor o báseň a o zdravý rozum. Židovské listy - redakčni blog (9th June of 2013 at 23:30). [online] Available at: http://zidovskelisty.blog.cz/1306/spor-o-basen-a-o-zdravy-rozum [Accessed 26.04. 2019].

About the Contributor: Štěpán Balík (1976), Assistant Professor at the Faculty of Arts, University of South Bohemia in České Budějovice, a member of The Centre for the Study of the Holocaust and Jewish Literature at the Faculty of Arts, Charles University. 